\title{
Małgorzata Czerny
}

Poznan University of Economics and Business

Faculty of Management

Department of Accounting

e-mail: malgorzata.czerny@ue.poznan.pl

\section{The influence of religious principles on the formation of the accounting system*}

\begin{abstract}
Factors such as different cultural determinants undoubtedly affect "the shape" of the economy. Mueller, Hofstede and Gray, among others, have studied the impact of the cultural factors on an economy, especially in fields such as accounting. Reflections on the topic have also appeared in the Polish literature, although relatively late. One of the cultural factors is, beyond doubt, religion, forming some ethical attitudes through the transfer of certain values which become the guiding principles for individual actions, exerting an obvious influence on the applicable standards in a given society. The author does not claim to consider the relations between religion and ethics, as only issues concerning a possible to demonstrate influence of religious norms on accounting are raised in the article. The aim is to discuss briefly the impact of Christianity, Islam and Confucianism on accounting systems and practices based on literature studies. In conclusion, the question arises about the sense of the convergence of accounting standards, at least in the context of the current efforts undertaken in this field.
\end{abstract}

Keywords: ethics, religion, accounting

JEL Classification: M41, N20, Z12

\footnotetext{
* The article published in the framework of the project "Popularisation of the latest economic knowledge among youth" implemented in cooperation with the National Bank of Poland as part of the economic education programme. The article is an updated version of the paper published in Polish in the Annales. Ethics in Economic Life, 19(2), 111-128.
} 


\section{Introduction}

There is no doubt that many of the cultural determinants impact the shape of an economy. The impact of cultural factors on the economy, as well as its specific fields, including accounting, has been studied, among others, by Mueller (1967), Hofstede $(1980,1984)$ and then by Gray (1988). Lately, reflections on the topic have also appeared in the Polish literature (cf. Adamek 2009, 2011a, 2011b, 2012; Bonca, 2010; Kamela-Sowińska, 2006). ${ }^{1}$ One driving cultural factor is religion, cultivating ethical attitudes through the transfer of certain values that become the basic principles for individual actions influencing the applicable standards in a given society. The author does not claim to consider the relations between religion and ethics, or, business ethics. The focus in the article is on the influence of religious norms on accounting. The literature review demonstrates that Christianity, Islam and Confucianism have affected the accounting practices.

Cultural, social, economic and political factors (different in many countries) have a significant impact on expectations formulated in relation to financial statements in terms of information that they should provide as well as tasks faced by the accounting system. Each country uses the accounting system-despite its far-reaching standardisation - in a manner adapted to the specificity of these factors, harmonised with the general principles on which the functioning of the economic system is grounded (cf. Adamek, 2012, pp. 28-38, 122; Diaconu \& Coman, 2006, p. 30).

The literature and business practices reveal the necessity of maintaining high ethical standards in accounting, information and auditing system of the past and present financial management of the economic entities/organisations. Religion can be held, at least, partially responsible for such ethical accountability. Due to the role, that accounting has to fulfil, the reliability of the information provided by it is an indispensable condition of its existence and the demand for data generated by this system. This reliability is also necessary for the justification of the privileged status of the accounting profession in the public service-with trust and honesty as its foundations. ${ }^{2}$ An individual's ethics is an internal belief system that determines how this individual perceives the world; the impact of the external environment in this area is undisputed. Culture and ethics converge; the individuals develop their ethics on their culture. Religious beliefs are, largely, determinants of the proper ethical behaviour. ${ }^{3}$

\footnotetext{
${ }^{1}$ The ethical principles of the auditing or accounting professions are often considered (cf. Szczepankiewicz, 2007; Szczepankiewicz \& Dudek, 2007).

${ }^{2}$ This trust has been damaged in recent years by a number of public financial scandals (e.g.: the case of Enron) (cf. Satava, Caldwell \& Richards, 2006).

Sources can be seen in the mid-1990s, when (mainly in the USA) a profound change took place in the business system of values - ethical values from absolute ones (rooted in Judeo-Christianity) started to evolve towards relativism (cf. Lehman, 2004; Onyebuchi, 2011, pp. 275-276).

${ }^{3}$ Ethics as defined by Onyebuchi is the "systematic study of conduct based on moral principles, reflective choices, and standards of right and wrong conduct" (cited after: Young, 2013, p. 27; cf. Wiseman \& Young, 2014).
} 
The development of accounting systems in countries with different cultural determinants, where value systems developed on the basis of Christian beliefs, Islam, Confucian philosophy or Buddhism, indicates that religion unambiguously (though to a varying degree) affects the practice in this the field.

\section{Christianity and the "Western" accounting model}

The idea of early Christian and then Roman Catholic sacrum-profanum weighs heavily on the Christian way of understanding and assessment. Every activity and action in the past was clearly defined as sacred and sacrosanct (sacrum) or earthly (profanum). Money and everything related to it was considered as "worldly" (the profanum sphere). ${ }^{4}$ A kind of justification for economic activity, including accounting, as a secular practice linked to usury condemned and forbidden by the Church was the support provided for sacrum (God's work, the Church's activity) by procuring funds for its functioning (through donations or the purchase of indulgences) (Carmona \& Ezzamel, 2006, after Young, 2013, pp. 35-36).

Protestantism marked a new perspective in the perception of economic activity. The recommendations of Reformed Christianity are spelled out in the quotation from the letter of Saint Paul to the Corinthians (10:31): "so [...] whether you eat or drink, or whatever you do, do all to the glory of God" ("Biblia Tysiąclecia," 1982, p. 1130). Every manifestation of human activity can therefore be treated as an action for the glory of God, depending on one's intention.

Classical economics of the $18^{\text {th }}$ century was based largely on Protestant ethics, glorifying diligence and praising the accumulation and multiplication of wealth obtained through hard work (in contrast to Catholic ethics, emphasising the "non-utilitarian" virtues). As Nasr says, the ethical, religious roots of Western economics were quickly marginalised. ${ }^{5}$

The original division into sacrum and profanum, on the one hand, and the justification for the accumulation of worldly goods, on the other hand, have strongly influenced the entire Western culture. In the course of its development, Western civilisation has become increasingly materialistic. Faith no longer has political or economic consequences to the same degree as before (Afifuddin \& Siti-Nabiha, 2010, p. 1143 et seqq.). In principle, since the end of the Middle Ages, Christian institutions have gradually ceased to emphasise the consonance of the Christian faith with business activity, even in the context of public service. Secular Western culture, whose implications were indicated in the Introduction to

\footnotetext{
${ }^{4}$ This conviction can be based on the Gospel of Saint Matthew (6:24): "No one can serve two masters [...] You cannot serve God and money" ("Biblia Tysiąclecia," 1982, p. 1130).

${ }^{5}$ According to this author, the publication of works written by Smith, Ricardo and J.S. Mill presenting their economic concepts that stress the "excessive" importance of the accumulation of wealth on par with entrepreneurship (this concept has started to lose its original meaning of "economic activity", becoming more commonly identified simply with the ability to "get rich") has led to the situation in which, on the one hand, economics has become a scientific discipline, and on the other hand, a form of social activity, if not detached from ethics, then increasingly often diverging from it (Nasr, 1993, p. 205).
} 
this article, has to some extent "freed up" business (including accounting) from religious morality based, among others, on empathy and taking into account in one's conduct the rights of other people or the increasingly abstract "social good" (p. 1143). This fact has had serious consequences for modern business practices in Western culture, resulting in the "reorientation" of business-including professional accountants-from the perspective of "social service" to "personal achievements" and "money making," considered an indicator of professional success and social status. If ethical norms, including personal views on what is right and wrong, become relative, it allows one to make one's own decisions based on personal opinions, disregarding general principles, which potentially leads to corruption. If relativism becomes the norm, people find ways to circumvent the law without feeling any discomfort of conscience. A person accepting such an ethical system assumes at the same time that the principles work differently in business than in other aspects of life. This model is based on self-deception and "abstract greed" (Satava, Caldwell \& Richards, 2006, p. 273).

Economic liberalism, within which the Western model of accounting developed, is, in fact, a result of ideas derived from various sources (such as the neoclassical school of economics, the works of Smith or Friedman) (Holton, 1992, pp. 54-69). The current principles of this tradition can be summarised as follows:

(1) private property rights,

(2) individualism,

(3) personal utility (which can also be seen as self-interest or selfishness),

(4) rationality,

(5) market self-regulation.

Capitalist society is based on the doctrine of individual private property. It recognises public property only when it is necessary (e.g., when social good requires it), and state ownership when experience indicates the need to nationalise certain branches of the economy. Respect for private property is one of the most important basic principles of liberalism that affects the accounting system and its standards. The Western accounting model is based on microeconomics (cf. Jaworska, 2011; Taheri, 2011). Thus, accounting is focused on the enterprise as an entity that influences through its market activity the entire economy and on the provision of financial information for investors and creditors as well as the managerial staff.

According to the economic liberalism, the maximisation of profit and the individualisation of benefits become the main goals of business management. Thus, accounting as an information system focuses on the profit and loss account, evaluates the company in terms of revenues and expenses (i.e., the revenue-cost approach to determining profits) (cf. Jaworska, 2011; Taheri, 2011). Similarly, to the entire economic system, accounting is based on the entity theory. The basis of business, defining its legal framework, is secularity, and with it, the dichotomy between business and morality that applies to the accounting system, has developed as part of economic liberalism. The accounting policy is primarily focused on goals (to a much lesser extent on values), and the approach to accounting principles is purely technical, albeit limited by codes of professional ethics. In this 
model, the concept of time value of money is widely recognised and used, and charging an interest rate is acceptable (Bonca, 2010, p. 50 et seqq.; Jaworska, 2011 , p. 80). In terms of the type of information identified by the accounting system, their scope covers internal, tangible economic events subject to monetary measurement, while maintaining the principle of limited disclosure; therefore, the historical cost becomes the measurement.

\section{The influence of Islamic religious principles on the formation of the accounting system and financial reporting in Muslim countries}

Islam, as its faithful emphasise, is more than just a religion-it is a culture, a worldview and a lifestyle for the faithful to practice (Hamid, Craig \& Clarke, 1993). Islam, as perhaps no other religion, interferes in many manifestations of its followers' activity, ${ }^{6}$ and therefore affects the way in which a business is conducted. Unique solutions in the ways in which the businesses are conducted, and the bookkeeping practices in Muslim society are a great example of how far accounting can be integrated into fundamental religious principles (Maali \& Napier, 2010). In Islam, there is no concept of sacrum and profanum, as these spheres permeate each other. Earthly life is connected with the spiritual and religious spheres, everyday actions prepare the faithful for "higher" acts of a spiritual dimension. This also applies to business activity and, therefore, accounting (Afifuddin \& Siti-Nabiha, 2010, p. 1134 et seqq.). The Islamic economy, limited by religious law, operates based on three fundamental principles (As-Sadr, 1994, pp. 51-55):

(1) multifaceted ownership (complex and heterogeneous),

(2) economic freedom within specified limits,

(3) social justice.

Sharia law formulates special demands with regard to financial practices, absolutely binding for followers and forming an original model, different from the Western one, of the functioning of economic systems in Muslim countries. These postulates also have a significant impact on accounting standards, its practices and the formula of financial statements. They come down to three prohibitions (cf. Adamek, 2012, p. 47 et seqq.; Bonca, 2010, pp. 50-52, 66-81; Czerny, 2015, pp. 22-23, 25; Moin, 2013, pp. 4-5; Samad, 2004, pp. 3-5):

(1) the prohibition of riba (interest) - no possibility of charging interest,

(2) the prohibition of gharar (speculation) - any activity involving speculative risk is prohibited and the faithful are obliged to avoid it; speculation in essential necessities and natural resources is particularly disgraceful,

\footnotetext{
${ }^{6}$ Muslims believe, as do the Christians, that they will answer for their deeds to God on the Day of Judgment, receiving rewards or punishments accordingly. Therefore, they must obey Sharia law at every moment and in every aspect of life. Sharia law along with the Quran creates a universally accepted code of ethical norms that determine arbitrarily what is wrong and what is right in the eyes of God.
} 
(3) the prohibition of involvement in the production or consumption of goods that are haram (prohibited from the religious point of view), and one requirement - to pay zakat, which is an obligatory type of tax in Muslim countries.

The accounting system in Muslim countries has developed and formed on the basis of the above-presented principles, hence its considerable difference from Western standards. The basic discrepancy in the perception of the need to comply with certain standards and solutions as well as in the attitude towards their formulation and refinement between the representative of the Islamic world and the West results from a completely different perception of the law. In the West, laws are made to adapt to the existing situation, to regulate it, while in the Muslims' opinion it is the situations that need to be shaped in order to conform to the Law of God (Taheri, 2011, p. 5; cf. Mutahhari, 1993, p. 206). At the same time, as in all major religions, Islam requires ethical behaviour in contacts with others (responsibility and ethics are highly valued in this culture) and respect for resources.

Islam accepts ownership in various forms without favouring one of them (AsSadr, 1994, pp. 98-114). All property belongs to God, man is only its trustee; the ownership of the property is connected with obligations towards other people and consideration of their rights; however, the scope of ownership (of any type) may be changed and interpreted depending on the needs and circumstances. ${ }^{7}$ The principle of limited economic freedom follows indirectly from this fact. Everyone is a guardian of social trust and individual property rights should be limited by the public interest. The success of the individual and society depends on the balance between the spiritual and material needs of man. The system of distribution of goods and capital in Islamic society accepts differences in wealth but rejects excessive social stratification. Fair distribution of income is implemented by means of the prohibition of charging interest and the obligatory zakat tax. Accounting, therefore, provides the financial information relevant to government and society as a whole (i.e. the major users of financial statements). Moreover, the fundamental issues are tax revenues, such as $z a k a t^{8}$ and others, as well as the manner of their spending. The Islamic accounting model is therefore based on macroeconomics.

On a micro scale, Islamic financial statements must provide information about the economic and social significance of decisions made in a given business entity, ${ }^{9}$ useful for assessing the efforts of the management and all company employees made in order to exploit the resources necessary to achieve the company's business and social goals in accordance with legal and ethical standards. In addi-

\footnotetext{
${ }^{7}$ There is an ongoing discussion between Islamic lawyers and economists whether the state can enforce a certain flow of goods and capital as well as their distribution in accordance with the requirements of social justice, from the affluent to the poorest and most needy citizens, or whether this should be done only "through persuasion" (cited after Rahman, 1997, p. 3 et seqq.; cf. Chapra, 2006; Shari'ati, 1987; Siddiqi, 1981).

${ }^{8}$ Adamek (2012, p. 53) points out that since the goal of Islamic accounting is to provide information that is important from the point of view of zakat, this proves the existence of a weak link between the task that the Islamic accounting faces and the concept of objectivity.

${ }^{9}$ Such as the treatment of employees, honest payment of taxes, charitable activities, and the impact exerted on the natural environment.
} 
tion, financial statements should provide information allowing for the assessment of management effectiveness in the field of income distribution in terms of achieving economic justice. The financial report should include a full and fair picture of the company and its activities in accordance with the principles contained in Sharia law. All activities that are not compliant with this law are haram, and therefore, considered illegal and immoral (Baydoun \& Willett, 1997, p. 19). At this point, Sharia law is consistent with the known and recognised in the Western world principle of "true and fair view."

Another characteristic of this accounting system is the fact that it is based on the theory of ownership. This is because in the light of Islam as a canon of principles, everyone is responsible for their own actions-religious negligence as well as economic and financial activities in which they are engaged. There should be no separation between an enterprise as an economic entity and its owner, who as the owner of assets is responsible for liabilities and receivables. It would be immoral to release the owner from liability for company debts while maintaining the right to profit. It would be a kind of forbidden speculation (the possibility of obtaining benefits excessive in relation to the risk undertaken) (after Taheri, 2011, pp. 4-5; cf. Belkaoui, 1993, pp. 166 et seqq., 233; Khan, 1994, p. 5 et seqq.).

The consequence of accepting the theory of ownership is the recognition of the balance sheet as the most important among financial statements (the static approach). The interaction between the company and the environment is closely monitored (in the social context), especially the income distribution mentioned above. As Taheri (2011) emphasises, in this model, the profitability of the enterprise is a derivative of responsible management of assets and liabilities and keeping the balance between assets and liabilities (p. 5). The perception of business activity through the prism of revenues and costs orients accounting towards cost management (striving to minimise costs), which often leads to "inhuman conduct" (Adamek, 2012, p. 54). Rules that are not in line with Islamic teaching, i.e. the historical cost, should not be the basis for property valuation; hence, valuation should be carried out, for example, based on current exit prices (Taheri, 2011, p. 5; cf. Gambling \& Karim, 1991, pp. 39, 84, 88-99).

One of the fundamental differences between the Western and Islamic economies, reflected in the formation of the accounting system, is the approach to tax issues. In Western countries, the tax is treated as a burden that companies should avoid if possible (which results from the focus on profit and assessment of the effectiveness of business operations from this perspective). For a Muslim, zakat is "alms" (the literal meaning of the word) which the people poorer than the ones whose assets exceed a certain limit are entitled to. It is collected and distributed by the state which implements the principle of social justice; tax evasion or attempts to reduce the amount of tax paid are both a sin and an impoverishment of society, and cannot be considered legal. The obligation to pay zakat causes a number of problems for accounting, as the zakat rules are inconsistent with the generally accepted accounting practice (GAAP). The main problem is the incompatibility of the whole zakat concept with the precautionary principle. It claims that while carrying out valuation, one should ensure that the value of assets and revenues is 
not overstated and liabilities and costs are not understated. However, lowering the value of assets would mean a lower tax liability. In the context of the tax-related approach discussed above (Islam encourages generosity), it would be a sin. By nature, the Muslim accountant focuses on avoiding underestimating the value of assets or inflating the value of liabilities, acting against the precautionary principle. Another problem is the method of valuation of inventories and receivables. Zakat is paid only on the surplus of (Rahman, 1997, p. 4):

(1) assets constituting the actual property of the company,

(2) productive assets,

(3) assets held by the company throughout the whole year.

In accordance with generally accepted accounting principles, inventories should be valued at the lower of the two values: the manufacturing cost or the market value (usually the net sales value, less often the purchase value or replacement value). In practice, as noted by Rahman (1997), citing Clarke (1996, p. 204), the manufacturing cost is most often used in the balance sheet valuation. Meanwhile, only the selling price is significant for zakat purposes. Muslims, following the GAAP recommendations in valuing inventories, would break their own law (Rahman, 1997, p. 4). Regarding valuation of receivables, zakat is only payable on net receivables. The zakat tax obligation does not take into account the existence of doubtful debts and no provisions for bad debts are created (p. 4).

The necessity of applying Sharia law means that Islamic accountants have problems to comply also with other accounting principles commonly adopted in Western civilisation, such as the principles of monetary measurement. It leads to a limitation of the scope of information relevant to the Islamic recipient of the accounting report, which cannot be expressed with this measure. The abovepresented differences result from an alternative way to the Western one of defining money used in Islamic economics. Money is not referred to as "capital" but as a "medium of exchange." "Capital" comprises only resources that can be used in the production process. ${ }^{10}$ Under the conditions of inflation, the currency loses the attribute of a "fair" and "honest" unit of measurement. Islamic economists, therefore, propose the use of the replacement cost, the current value model or basing the value of money on the precious metal parity (Adamek, 2012, pp. 59-60). In addition, the accrual principle, which is one of the most important accounting principles, is controversial. Proponents of this principle argue that it is an instrument for correctly estimating wealth, a basis for calculating zakat, and it also harmonises with the majority of Islamic financial products. Numerous opponents indicate, however, that according to the accrual principle, the entity is forced to pay zakat on assets that it has not actually received. This principle also undermines the basic assumptions of the mudaraba contract, based on the distribution of cash profits, which is widely used in business contracts in Islamic countries. Its popularity is due to the fundamental prohibition of charging interest. The rationale is the belief that capital should be invested productively (Rahman, 1997, pp. 5-6;

\footnotetext{
${ }^{10}$ Money does not meet the requirements of such definition of "capital" (neither as a banknote nor as a coin - it has value only as a material that was used to create it) (cf. Behesh'ti, 1992, p. 126; Bonca, 2010, p. 84; Czerny, 2015, pp. 21-22; Kamali, 1994, pp. 25-36; Zaman, 2005, pp. 27, 31 et seqq.).
} 
Taheri, 2011, pp. 5-6). According to the religious message, one can earn only through one's own work and cannot multiply capital based on the use of someone else's property. In practice, therefore, the interest rate cannot apply. With an emphasis on deriving income from an exchange, which as an ex-post income is a determinant of economic success and multiplies wealth, the Islamic doctrine treats interest as ex-ante income, undue and immoral payment, as it is determined without relation to the outcome of the economic venture (Adamek, 2012, p. 46). Therefore, the key element of Islamic banking, apart from providing interest-free funds, is the concept of profit and loss sharing (PLS). In accordance with Sharia rules, the parties to the transaction must divide both profits and losses resulting from a given undertaking (cf. Accounting and Auditing Organization for Islamic Financial Institutions, 2010; Bonca, 2010, pp. 83-85; Iqbal \& Mirakhor, 1987, p. 112 et seqq.).

To sum up, although the practical dimension of accounting is perceived in Muslim countries as a kind of transaction registration technique, its theoretical assumptions differ fundamentally from the Western, American-British model. This causes a number of difficulties in adjusting Islamic accounting to applicable "global standards" (GAAP or IFRS). Due to the absolute necessity of observing religious norms, a different purpose of financial statements and the hierarchy of their users in Muslim countries, "conventional" financial statements cannot be applied. Hence the consistent development by the Accounting and Auditing Organisation for Islamic Financial Institutions in recent years of its "own" accounting standards, is in line with Sharia law, which is to apply in all Muslim countries.

\section{Confucianism and Asian accounting models}

Confucianism is a philosophical-religious system strongly associated with the Asian continent (such as Buddhism or Islam). The civilisation of Asia differs from the West by an exceptionally strong system of duties and obligations that bind community members (cf. Drelich-Skulska, 2007; Gawlikowski, 2001, 2009). The teachings of Confucius have had a strong impact not only on the shape of social organisation, including the way the economy functions but also on the perception of the role of the accounting system in business - and thus the formation of this information and audit system. The teachings can be generally summarised by the following theses (Drelich-Skulska, 2007, p. 721; cf. Mikułowski-Pomorski, 1999, p. 108):

(1) stability of society is based on the inequality of interpersonal relations;

(2) the family is the prototype of a social organisation;

(3) "virtuous conduct" is encapsulated in the slogan: treat others the way you would like to be treated;

(4) virtue in relation to human life goals consists of nurturing abilities, acquiring education, hard work and savings (understood as not spending more than necessary). 
Based on these assumptions, Asian countries have developed elements of the economic system that seem to be common for the entire continent (regardless of the political and economic system prevailing in a given country). The most important of these elements are (Nowakowski, 1990, p. 111):

(1) collectivism (the development of the individual and his or her activities are carried out within the group which is the point of reference and support),

(2) home (all social ties are based on the concept of family connections, family hierarchy and family responsibility),

(3) loyalty and reliability (people occupying a higher position in the hierarchy are morally obliged to be responsible for their subordinates),

in conjunction with social values widely accepted in Asia such as:

(1) social order and good organisation,

(2) respect for tradition,

(3) harmony in society,

(4) respect for authority,

(5) ensuring accountability of public officials,

(6) freedom of speech.

These elements determine not only the way societies function but also how business should be conducted (bin Mohamad, 1999, p. 157). Confucianism emphasises cooperation as an expression of harmony that should characterise a society, therefore, competition is treated as a non-productive factor. It emphasises that profit and ownership should not be a motive for human activity (it is worth noting that competition "in the industry" in Asian markets is much milder than in the Western world).

Bloom and Solotko (2003) indicate the relationship between the doctrine of Confucianism and accounting - first, the historical stability of the form and structure of accounting and its adaption to traditional practices, which results from the deep respect of Asians for tradition in general (p. 30). It is worth noting that up to the 1920 s, the use of the three-column record as a tradition-enshrined model of financial reporting technique was common in Asia (Gao \& Handley-Schachler, 2003, p. 55). Additionally, the type of information provided by Asian accounting systemsmainly of a macroeconomic nature (as in Islam, the recipients are primarily the state administration bodies, which is influenced - apart from historical determinants - by collectivist tendencies and respect for the hierarchy in Asian countries). Respect for traditional solutions also manifests itself in the static nature of Asian financial reporting (the current balance sheet is treated as a historical "government census" delivered to the provincial governor or "courtier" by minor officials), rarely supplemented with measurement and calculation of profits and losses.

The influence of the Confucian doctrine is also noticeable when it comes to the legal regulation of accounting in Asian countries. This regulation is usually based on a minimal codification of principles and rules that safeguard the social good (it is perceived through the prism of the relationship between the role and importance of personal development, loyalty as well as ethics and morality of the individual as factors determining and increasing the benefits of society). 
Conservatism and excessive risk avoidance (the attachment to the historical cost, smoothing of income varied over time) are other characteristics of the accounting system and accounting practices in Asian countries that can be linked to the Confucian system of rules.

A certain contradiction can be noted between nepotism and discretion that characterise Asian business activities (resulting from Confucian subordination to the virtue to loyalty - towards the state, family, friends) and the approach to disclosing financial statements, which in turn is based on such values as honesty and truthfulness. Honesty and truthfulness are not generally in contradiction with loyalty but may prove to be contrary to the discretion and respect owed to the elders, superiors or family members (the virtue ranked very high in the Confucian values system). In principle, however, the audit function of accounting is accepted. Auditing (e.g., of accounting books) is justified (it is consistent with the concept of loyalty and does not undermine trust), as the transparency of information, its verifiability, fosters openness, which is also one of the Confucian virtues. It also favours maintaining the social order and responsibility of public officials.

In general, accounting, as well as people dealing with it professionally, are subject to a kind of discrimination in thus organised society. This is due to the assumption that every member of the society should be able to look after his or her finances and commercial transactions. In the strong hierarchy of social positions characteristic of Asian societies, the accounting profession is assessed relatively low, its mission - as the role of the accounting system-is servile (the role of an enumerator), and in many cases perceived as unnecessary. Accounting should provide data primarily on a macro scale, useful for the authorities, providing insight into the state of assets and the condition of the entire economy as well as the well-being of society (serve the public good). Its audit function is relatively best perceived and understood.

\section{Conclusions}

The above-presented short review of accounting systems operating in various cultures in the context of religious principles prevailing in these cultures clearly indicates that they have developed differently, depending on the impact of cultural factors. It seems that among the three accounting systems discussed in the article, accounting widely regarded as "conventional", more specifically its BritishAmerican model, is currently the least often linked with religious principles. However, as already indicated, the need for preserving high ethical standards, which is considered necessary in the case of accounting, also points to a connection with religion-Christianity-when the conventional model is taken into account. Most ethical systems are in their fundamental principles consistent with its message, and some of them have grown because of religious doctrine. Accounting systems that have developed in Asian countries are closely linked to the religious and philosophical doctrines of those regions. The strongest impact of a religion is 
visible on the Islamic accounting. However, since accounting as a system has not been created and developed "for itself" but within the economic system, there is no doubt that the religious factor had in the past (and still has, at least in some cultures) an impact on its formation (just as it has influenced the development of different economic models). One can only debate on the strength of this influence. At the same time, the question arises about the reasonableness of far-reaching standardisation of accounting and the actual possibility of its convergence. Proponents of the standardisation process point to its advantages: it is to improve the adherence to the basic accounting principles - consistency and comparability. This would allow foreign investors to read the content of financial statements in a consistent manner, enabling them to make better decisions (Zarzeski, 1996, after Young, 2013, p. 40). However, the question arises as to whether the harmonisation of standards and principles to which the accounting system is subjected, advanced far enough, will not result in, contrary to the underlying assumptions, the deterioration of the usefulness of financial statements and, hence, their quality. Cultural values, including religion, have shaped differently both economic systems and organisational culture, and-what this article aims to prove-also accounting practices. With regard to financial reporting, the circle of its recipients varies and different expectations are formulated as to the information that it should provide. These differences cannot be easily reconciled by implementing a universal accounting standard as a specific role model for all. It is worth noting that the accounting standardisation process is - as for now-a kind of "imposition" of Western accounting practices on the globalising world. Breaking the accounting out of its economic and cultural context will create a model that will continue to be the most useful for the "Western" recipient. Moreover- the image of the company included in the financial statements, although easily understandable for the recipient, may be distorted, as it does not take into account the specifics of the social, political, legal and economic determinants of the environment in which the company operates. ${ }^{11}$ Standardisation in its present form is not seen as integration, and in many countries, it is perceived as an arrogant attempt to impose Western solutions, without considering different cultural patterns, as if based on the conviction that Western culture and its standards are better than others (Young, 2013, p. 41; cf. Hamid, Craig \& Clarke, 1993).

It seems that these issues will gain further importance in the future, as in the world of cultural differences, the universal accounting standard is extremely difficult, if at all possible, to develop, and the process of accounting harmonisation should take into account this fact where necessary. Otherwise, it will not meet its goals. Even in an era of progressive globalisation, it cannot be expected that entire societies will quickly "reorient" their fundamental systems of values.

\footnotetext{
${ }^{11}$ The need to consider these factors, as well as the 'needs of society', has been already mentioned by Mueller (1967), and more recently by Oluku and Ojeka (2011, p. 917). Also Zarzecki, discussing the advantages of harmonising the accounting system, draws attention to the fact that "countries have already established markets and financial needs" as well as "developed accounting standards" - all based on the "cultural context" (after Young, 2013, p. 40).
} 


\section{References}

Accounting and Auditing Organization for Islamic Financial Institutions. (2010). Sharia standards for Islamic financial institutions. Bahrain: Accounting and Auditing Organization for Islamic Financial Institutions.

Adamek, J. (2009). Rachunkowość w kręgu kultury islamskiej. Zeszyty Teoretyczne Rachunkowości, 49(105), 7-17.

Adamek, J. (2011a). Kultura a rachunkowość. Prace Naukowe Uniwersytetu Ekonomicznego we Wrocławiu, 193.

Adamek, J. (2011b). Kulturowe uwarunkowania krajowych systemów rachunkowości w świetle koncepcji wymiarów subkultury rachunkowości S. Graya. Zeszyty Teoretyczne Rachunkowości, 62(118), 7-22.

Adamek, J. (2012). Kulturowe uwarunkowania rachunkowości $w$ świetle założeń i praktyki rachunkowości islamskiej i chińskiej. Warszawa: CeDeWu.

Afifuddin, H. B., \& Siti-Nabiha, A. K. (2010). Towards good accountability: The role of accounting in Islamic religious organisations. World Academy of Science, Engineering and Technology. International Journal of Social, Behavioral, Educational, Economic, Business and Industrial Engineering, 4(6), 1141-1147.

As-Sadr, M. B. (1994). Iqtisaduna (our economic) ( ${ }^{\text {nd }}$ Edition). Teheran: World Organization for Islamic Services.

Baydoun, N., \& Willett, R. (1997). Islam and accounting: Ethical issues in the presentation of financial information. Accounting, Commerce \& Finance: The Islamic Perspective, 1(1), 1-25.

Behesh'ti, S. M. (1992). Islamic economics. Teheran: Fajar Press.

Belkaoui, A. (1993). Accounting theory. New York: Dryden Press.

Biblia Tysiaclecia ( $3^{\text {rd }}$ Edition). (1982). Poznań-Warszawa: Wydawnictwo Pallottinum. https: $/ /$ www.biblegateway.com/passage/?search=Matthew $+6 \% 3 \mathrm{~A} 24-34 \&$ version=ESV

Bloom, R., \& Solotko, J. (2003). The Foundation of Confucianism in Chinese and Japanese accounting. Accounting, Business \& Financial History, 13(1), 27-40. doi: 10.1080/ $09585200210164566 \mathrm{c}$

Bonca, M. A. (2010). Islamskie instrumenty finansowe. Warszawa: Wydawnictwa Akademickie i Profesjonalne, Akademia Leona Koźmińskiego.

Carmona, S., \& Ezzamel, M. (2006). Accounting and religion: A historical perspective. Accounting History, 11(2), 117-127. doi: 10.1177/1032373206063109

Chapra, M. U. (2006). The Islamic welfare state and its role in the economy. In A. Khurshid (Ed.), Studies in Islamic Economics. Leicester: Redwood Burn.

Clarke, F., Craig, R., \& Hamid, S. (1996). Physical asset valuation and Zakat: Insights and implications. Advances in International Accounting, 9, 109-208.

Czerny, M. (2015). Wplyw zasad religijnych islamu na sprawozdania finansowe - zarys problemu. Teoria i historia rachunkowości, conference materials - UEP "Rachunkowość Warta Poznania”, Poznań.

Czerny, M. (2016). Wpływ zasad religijnych na ukształtowanie systemu rachunkowości. Annales. Ethics in Economic Life, 19(2), 111-128. 
Diaconu, P., \& Coman, N. (2006). Accounting research from the globalization perspective. International Journal of Human and Social Sciences, 1(1).

Drelich-Skulska, B. (Ed.) (2007). Azja-Pacyfik. Obraz gospodarczy regionu. Wrocław: Wydawnictwo Akademii Ekonomicznej im. Oskara Langego we Wrocławiu.

Gambling, T. E., \& Karim, R. A. A. (1991). Business and accounting ethics in Islam. London: Mansell.

Gao, S. S., \& Handley-Schachler, M. (2003). The influences of Confucianism, Feng Shui and Buddhism in Chinese accounting history. Accounting, Business \& Financial History, 13(1), 41-68. doi: 10.1080/09585200210164566d

Gawlikowski, K. (2001). Jednostka i władza w cywilizacji wschodnioazjatyckiej. In K. Gawlikowski, \& E. Potocka (Eds.), Korea: doświadczenia i perspektywy. Toruń: Wydawnictwo Adam Marszałek.

Gawlikowski, K. (2009). Konfucjański model państwa w Chinach. Warszawa: Instytut Studiów Politycznych Polskiej Akademii Nauk. http://www.isppan.waw.pl/sub page/cbap/wp/isp_konfucj_model_panstwa.pdf

Gray, S. J. (1988). Towards a theory of cultural influence on the development of accounting system internationally. Abacus, 24(1), 1-15. doi: 10.1111/j.1467-6281.1988. tb00200.x

Hamid, S., Craig, R., \& Clarke, F. (1993). Religion: A confounding cultural element in the international harmonization of accounting? Abacus, 29(2), 131-148. doi: 10.1111/ j.1467-6281.1993.tb00427.x

Hofstede, G. (1980). Culture's consequences: International differences in work-related values. Beverly Hills-London: Sage.

Hofstede, G. (1984). Cultural dimensions in management and planning. Asia Pacific Journal of Management, 1(2), 81-99.

Holton, R. (1992). Economy and society. London-New York: Routledge.

Iqbal, Z., \& Mirakhor, A. (1987). Islamic banking. Washington: International Monetary Fund.

Jaworska, E. (2011). Specyfika rachunkowości islamskiej. Wybrane zagadnienia. Zeszyty Naukowe Uniwersytetu Szczecińskiego, 32.

Kamali, M. H. (1994). Tas'ir (price control) in Islamic law. American Journal of Islamic Sciences, 11(1), 25-36.

Kamela-Sowińska, A. (2006). Rachunkowość od antropologii do międzynarodowych standardów. In T. Kiziukiewicz (Ed.), Rachunkowość w zarządzaniu jednostkami gospodarczymi. Szczecin: Katedra Rachunkowości Uniwersytetu Szczecińskiego, Katedra Rachunkowości Akademii Rolniczej w Szczecinie.

Khan, M. (1994). Accounting issues and concepts for Islamic banking. London: International Conference on Developing Accounting Standards for Islamic Banks IIB I.

Lehman, G. (2004). Accounting, accountability and religion: Charles Taylor's Catholic modernity and the malaise of a disenchanted world. Fourth Asia Pacific Interdisciplinary Research in Accounting Conference. Singapore: University of South Australia, School of Accounting.

Maali, B., \& Napier, C. (2010). Accounting, religion and organisational culture: The creation of Jordan Islamic Bank. Journal of Islamic Accounting and Business Research, $1(2), 6-11$. 
Mikułowski-Pomorski, J. (1999). Komunikacja międzykulturowa. Wprowadzenie. Kraków: Wydawnictwo Akademii Ekonomicznej.

Mohamad, M. bin (1999). Rozważania o wartościach azjatyckich. Azja-Pacyfik, 2, 157-168.

Moin, M. S. (2013). Financial performance of Islamic banking and conventional banking in Pakistan: A comparative study. International Journal of Innovative and Applied Finance, 1(1), 1-22.

Mueller, G. (1967). International accounting. New York: Macmillan.

Mutahhari, M. (1993). Islamic economic. Teheran: Sadra Pub.

Nasr, S. H. (1993). A young Muslim's guide to the modern world. Cambridge: Kazi Publications Inc.

Nowakowski, M. R. (1990). Zarzadzanie operacjami zagranicznymi przedsiębiorstw japońskich. Warszawa: Zakład Nauk o Zarządzaniu Polskiej Akademii Nauk.

Oluku, M. D., \& Ojeka, S. (2011). The challenge of culture to international financial reporting standards convergence. Interdisciplinary Journal of Contemporary Research in Business, 2(12), 914-924.

Onyebuchi, V. (2011). Ethics in accounting. International Journal of Business and Social Science, 2(10), 275-276.

Rahman, S. (1997). Islamic accounting standards. http://www.ifew.com/insight/13036mon /accstds.htm

Samad, A. (2004). Performance of interest-free Islamic banks vis-à-vis interest-based conventional banks of Bahrain. IIUM Journal of Economics and Management, 12(2), $1-15$.

Satava, D., Caldwell, C., \& Richards, L. (2006). Ethics and auditing culture: Rethinking the foundation of accounting and auditing. Journal of Business Ethics, 64(3), 271-284. doi: 10.1007/s10551-005-0556-y

Shari'ati, A. (1987). Abu Zar (Companion of the Prophet). Teheran: Ershad Pub.

Siddiqi, M. N. (1981). Muslim economic thinking: A survey of contemporary literature. Leicester: The Islamic Foundation.

Szczepankiewicz, E. I. (2007). Wybrane aspekty i uwarunkowania realizacji zasad etyki przez audytorów wewnętrznych. Monitor Rachunkowości i Finansów, 9, 41-46.

Szczepankiewicz, E. I., \& Dudek, M. (2007). Etyka w działaniu audytora wewnętrznego. Zeszyty Naukowe Wyższej Szkoły Handlu i Rachunkowości w Poznaniu.

Taheri, M. R. (2011). The basic principles of Islamic economy and their effects on accounting standards-setting. http://www.docstoc.com/docs/166485067/The -basic-principles-ofIslamic-economy-and-their-effects-on-accountingstandards-setting

Wiseman, T., \& Young, A. (2014). Religion: Productive or unproductive? Journal of Institutional Economics, 10(1), 21-45. doi: 10.1017/S174413741300 026X

Young, M. (2013). Cultural influences on accounting and its practices. http://digi talcommons.liberty.edu/cgi/viewcontent.cgi?article $=1396 \&$ context=honors

Zaman, A. (2005). Islamic economics: A survey of the literature. International Institute of Islamic Economics. Religion and Development Research Program, Lead Research Institution: International Development Department, University of Birmingham.

Zarzeski, M. (1996). Spontaneous harmonization effects of culture and market forces on accounting disclosure practices. Accounting Horizons, 10(1), 18-37. 